Premiere Educandum: Jurnal Pendidikan Dasar dan Pembelajaran

Volume 8(2) 98 - 111 Desember 2018

Copyright (C2018 Universitas PGRI Madiun

ISSN: 2088-5350 (Print) / ISSN: 2528-5173 (Online)

Available at: http://e-journal.unipma.ac.id/index.php/PE

Doi: $10.25273 /$ pe.v8i2.2697

\title{
Permainan tradisional Yogyakarta sebagai sumber belajar alternatif berbasis kearifan lokal bagi pembelajaran di sekolah dasar
}

\author{
Muhammad Ragil Kurniawan \\ Fakultas Keguruan dan Ilmu Pendidikan Universitas Ahmad Dahlan Yogyakarta \\ email: ragil.kurniawan@pgsd.uad.ac.id
}

\begin{abstract}
This research aims to know about: a) variety of traditional games for children based on local wisdom in Yogyakarta. b) Traditional games character based on local wisdom in Yogyakarta to support learning in primary school education. This research is a qualitative descriptive study. The object of this research is a traditional game children (dolanan anak) in Yogyakarta. The method used is book analysis supported by interviews of experts and practitioners culture in Yogyakarta. Data analysis used is qualitative data analysis. The study showed that: a) There are at least 37 traditional games based in Yogyakarta. b) Based on 37 exiting traditional games, all off them have a wide variety of game characters. Starting from classification by user group (individual, small group, to very large group), based on the content (verbal, imagination, and physically), until based on competence contained (skill to singing, playing, thinking, to compete) all these categories exist traditional games types.
\end{abstract}

Keywords: traditional games, local wisdom, learning resources.

\section{Abstrak}

Penelitian ini bertujuan untuk: a) Untuk mengetahui ragam permainan tradisional anak yang berbasis kearifan lokal di Yogyakarta, b) Untuk mengetahui karakter permainan tradisional berbasis kearifan lokal di Yogyakarta guna mendukung pembelajaran di sekolah dasar. Jenis Penelitian ini adalah penelitian deskriptif dengan pendekatan kualitatif. Objek penelitian ini adalah permainan tradisional anak (dolanan anak) yang ada di D.I Yogyakarta. Penelitian ini menggunakan metode studi pustaka yang didukung oleh hasil wawancara dari ahli dan praktisi kebudayaan Yogyakarta. Analisis data yang digunakan adalah analisis data kualitatif. Hasil penelitian menunjukkan sebagai berikut: a) terdapat minimal 37 permainan tradisional yang ada di daerah Istimewa Yogyakarta. b) Dari ke-37 permainan tradisional yang ada memiliki ragam karakter permainan yang sangat luas. Mulai klasifikasi berdasarkan kelompok pengguna (individual, kelompok kecil hingga kelompok sangat besar), berdasarkan muatannya (bermuatan verbal, imajinasi hingga yang bermuatan fisik), hingga berdasarkan kompetensi yang terkandung (kompetensi bernyanyi, bermain, berpikir hingga berkompetisi) kesemua kategori ada jenis permainan tradisional yang masuk dalam masing-masing klasifikasi kelompok.

Kata Kunci: permainan tradisional, kearifan lokal, sumber belajar.

Histori artikel : disubmit pada 03 Juli 2018; direvisi pada 5 Agustus 2018; diterima pada 01 September 2018

\section{A. PENDAHULUAN}

Teknologi informasi dan komunikasi telah merasuk ke setiap lini kehidupan masyarakat. Di era TIK ini, aktifitas masyarakat sangat bergantung pada teknologi yang berbasis elektronik atau digital, mulai dari aktifitas formal hingga dengan aktifitas hiburan. Tidak luput dari jangkauan teknologi elektronik adalah aktifitas yang 
dilakukan oleh anak-anak. Di era teknologi digital ini tidak sedikit dampak negatif yang dirasakan masyarakat mulai dampak personal hingga dampak global. Salah satu dampak personal yang dialami anak-anak adalah phobia baru era digital yang sering distilahkan dengan nomophobia.

Nomophobia merupakan bentuk ketakutan baru di era modern untuk tidak terhubung dengan mobile phone dan internet (King dkk, 2014). Ketakutan atau phobia baru ini disebabkan ketergantungan yang berlebihan terhadap mobile phone dan jaringan internet. Penyandang phobia era digital ini sangat beragam, tidak terlepas didalamnya adalah anakanak usia sekolah dasar. Anak tidak bisa dipisahkan dengan gadged, games, dan semua yang berbai media elektronik dan internet. Salah satu dampak nomophobia yang dialami anakanak adalah anak menjadi lebih suka didalam rumah sehingga aktifitas fisik dan aktifitas sosial anak menjadi rendah. Hal ini secara tidak langsung akan berimbas pada kecerdasan sosial dan kecerdasan kinestetik anak. Dampak lain yang tidak kalah penting adalah, tercerabutnya anak dari konteks lokalitas dimana dia tinggal dan tumbuh. Hal ini senada dengan yang disampaikan Ruyadi (2010) bahwa selain aspek positif, globalisasi juga membawa dampak negatif terhadap melemahnya kearifan budaya lokal.

Dampak lain dari maraknya era digital adalah kemunculan budaya online. Salah satu pertumbuhan budaya online yang bertumbuh pesat saat ini adalah penggunaan media sosial. Laporan comScore yang dikeluarkan pada Januari 2010 menunjukkan jumlah pengunjung media social menjadi 770 orang atau meningkat sebesar $18 \%$ lebih banyak disbanding dengan tahun 2009. Penggunaan media sosial tersebut mendekati angka $70 \%$ dari jumlah pengguna internet di dunia. Mustafa\&Hamzah (2010) menengarai bahwa para peselancar dunia maya secara rata-rata mengakses laman jaringan sosial sebanyak 20 kali dalam sebulan dan menghabiskan waktu selama empat jam dalam sehari. Beberapa temuan diatas mengindikasikan bahwa media sosial sebagai salah satu aktifitas yang paling diminati oleh masyarakat dalam mengakses internet.

Di Indonesia, penggunaan media sosial juga mengalami pertumbuhan yang sangat pesat. Data yang dirilis salingsilang.com menyebutkan bahwa pengguna Twitter di Indonesia menghasilkan kira-kira $15 \%$ daripada keseluruhan tweet dunia dan ini menjadikan Indonesia menjadi negara ketiga terbesar pengguna Twitter. Tidak hanya Twitter, masyarakat indonesia juga banyak mengakses media sosial lain, diantaranya facebook. The New York Times merilis laporan hasil research pada April 2010 yang menunjukkan bahwa Indonesia menjadi salah satu dari tiga negara dengan pengguna Facebook terbanyak didunia. Negara lain yang juga menjadi negara pengakses terbanyak adalah Amerika Serikat dan Britania raya. Mustafa (2013) menguatkan bahwa jumlah pengguna Facebook di Indonesia sebanyak 24 juta pengguna atau $10 \%$ dari total penduduk Indonesia. Jumlah 
pengguna media sosial tersebut menjadikan Indonesia sebagai negara pengguna Facebook terbanyak kedua di dunia setelah Amerika Serikat.

Konsekwensi lain dari terpaan era digital adalah ketergantungan anak terhadap smartphone. Sesuai dengan hasil penelitian Husni dan Fatullah (2016) yang menemukan bahwa bahwa lebih dari sepertiga sampel surveinya mengatakan bingung dan bosan jika tidak berinteraksi dengan internet. Sisi negatif yang dapat muncul jika anak sudah mulai bingung saat tidak ada internet adalah potensi kecanduan anak terhadap internet. Jika anak sudah kecanduan dengan smartphone dan internet maka anak akan lebih suka menyendiri dan enggan untuk berinteraksi langsung dengan masyarakat sosial disekitar tempat tinggalnya. Dengan kata lain anak yang ketergantungan dengan gadged dan internetnya tinggi maka aktifitas sosial anak menjadi berkurang. Berkurangnya aktifitas sosial anak juga akan mengurangi kepekaan sosial anak. Di sisi lain, jika anak lebih suka menyendiri untuk berinteraksi dengan gadgednya, maka kecenderungan aktifitas kinestetiknya juga akan menurun. Hal ini akan berpengaruh pada perkembangan kecerdasankecerdasan siswa yang bermuara dari aktifitas kinestetik.

Dampak dari keberadaan teknologi digital dan internet serta maraknya gadget ini sudah selayaknya disikapi oleh dunia pendidikan. Salahsatunya adalah dengan meningkatkan aktifitas sosial dan kinestetik anak di lingkungan sekolah. Kedua aktifitas tersebut menjadi penting dikarenakan anak terus tumbuh di lingkungan sosial yang spesifik. Di sisi lain untuk mengenalkan anak pada budaya lokal tempat mereka tinggal dan tumbuh maka sekolah juga mempunyai peran untuk ikut serta menjaga budaya lokal masyarakat sekitar. Karena di era apapun, generasi kita tidak boleh tercerabut dari akar budaya bangsa (Anshory, 2013). Jadi kekhawatiran akan rendahnya aktifitas sosial-kinestetik anak serta kekhawatiran akan terkikisnya budaya lokal dapat diberi solusi dengan penerapkan permainan tradisional anak sebagai budaya lokal untuk meningkatkan aktifitas sosial dan kinestetik anak.

Pilihan atas permainan tradisional untuk digunakan dalam salah satu strategi meningkatkan aktifitas sosial dan kinestetik anak cukup beralasan. Hal ini karena karakter yang ada dalam permainan sesuai dengan karakter anak. Menurut Manguanwijaya (dalam Huizinga, 1990) karakter anak secara esensial adalah spontan, merdeka, tanpa pamrih, tanpa muslihat politik, atau dengan kata lain karakter tersebut adalah makna dari bermain dalam arti sangat luas. Anak dengan karakter dasar bermain sudah selayaknya juga dijaga seluruh potensi kemerdekaan yang dimilikinya. Diantara potensi yang dimiliki anak diantaranya adalah potensi kecerdasan IQ, EQ dan SQ, serta potensi kecerdasan majemuk (multiple intelligence). Sehingga anak tidak hanya didoktrin untuk mengasah satu aspek kecerdasan dari kecerdasan majemuk atau satu dari potensi otaknya saja, otak kanan maupun otak kiri saja. 
Tidak dapat dipungkiri, beberapa proses pembelajaran di sekolah masih banyak menitikberatkan pada satu aspek kecerdasan saja atau masih didominasi salah satu ragam keilmuan. Bahkan Prasetyo (2015) mensinyalir bahwa implementasi kebijakan pendidikan masih didominasi dari ilmu pengetahuan yang bersifat saintis- teknologis yang berangkat dari paradigma rasional dan empiris. Titik berat pada aspek sains dan teknologi menjadi indikator bahwa kecerdasan logis-matematis (dalam terminologi multiple intelligence) masih mendominasi orientasi proses pembelajaran. Dominasi kecerdasan logis-matematis pada proses tumbuh kembang anak dapat mengarahkan pada ketimpangan pemaksimalan kecerdasan otak anak, yaitu hanya mengasah otak kiri saja.

\begin{tabular}{llll}
\multicolumn{2}{c}{ Ditengan } & \multicolumn{2}{c}{ dominannya } \\
pengasahan otak & kiri & oleh \\
pendidikan pada & siswa & kita,
\end{tabular}
permainan juga memberi stimulasi untuk mengasah otak kanan manusia. Tidak hanya berhubungan dengan spontanitas olah gerak tubuh, permainan juga berhubungan dengan nilai keindahan yang diciptakan oleh permainan itu sendiri. Sifat indah tidak melekat secara inheren kepada permainan itu sendiri, namun mempunyai kecenderungan untuk berhubungan dengan berbagai unsur keindahan. Dalam bentuk-bentuknya yang lebih berkembang, permainan terjalin erat dengan irama dan keserasian, bakat-bakat yang paling mulia dari kemampuan persepsi estetis yang diberikan kepada manusia. Ikatanikatan antara permainan dan keindahan itu sangat erat dan banyak (Huizinga, 1990). Oleh karenanya, permainan tradisional layak untuk dimanfaatkan sebagai sarana dan sumber untuk mendukung proses pembelajaran.

Pemanfaatan permainan tradisional dalam proses pembelajaran salah satunya ditujukan untuk mengoptimalisasi aspek non kognitif siswa. Satu aspek perkembangan anak yang dapat terfasilitasi dengan baik dengan pemanfaatan permainan tradisional adalah aspek motorik dan pertumbuhan fisik anak (Yudiwinata, 2014). Tidak hanya mengembangkan aspek motorik, kinestetik dan sosial anak, permainan tradisional juga mengandung nilai karakter dan dapat menjadi sarana menjaga nilai-nilai budaya keIndonesiaan. Optimalisasi potensi pada anak bertujuan untuk menjaga nilai-nilai positif yang terkandung pada akar budaya bangsa.

Penanaman nilai-nilai positif yang mendorong terciptanya masa depan berkelanjutan menjadi penting karena manusia merupakan pusat dari pembangunan berkelanjutan tersebut. Nilai-nilai positif yang dimaksud, antara lain adalah: (1) menghargai nilai- nilai dan hak-hak semua manusia di seluruh planet bumi dan komitmen terhadap keadilan sosial dan ekonomi bagi semua, (2) menghargai hak-hak azasi manusia generasi mendatang dan komitmen terhadap tanggung jawab antar generasi, (3) menghargai dan peduli pada kehidupan komunitas dengan keanekaragamannya yang mencakup perlindungan dan perbaikan terhadap ekosistem planet bumi, dan 
menghargai keanekaragaman budaya dan komitmen untuk membangun toleransi budaya lokal dan global, perdamaian, dan nonviolence.

Potensi yang dimiliki permainan khususnya permainan tradisional anak di kawasan DI. Yogyakarta membuka peluang bagi pendidikan untuk kembali melihat potensi lokal yang dimiliki bangsa ini. Potensi yang ada pada permainan tradisional dapat di eksplorasi lebih mendalam agar dapat diambil nilai-nilai kearifan budaya lokal guna membentangi anak atas gempuran budaya global. Di era global ini, bangsa yang mampu mempertahankan budaya lokal terbukti berhasil bersaing di raah global. Dalam kasus ini telah dibuktikan oleh China, India, Jepang bahkan Korea Selatan yang telah sukses mempertahankan bahkan mengimport budaya lokal masing-masing untuk bersaing di era globalisasi. Oleh karenanya diperlukan analisis karakter secara umum tentang karakter permainan tradisional guna memudahkan komponen pendidik di sekolah dasar dalam memilih dan menggunakan permainan tradisional sebagai sumber belajar.

\section{B. METODE PENELITIAN}

Penelitia ini merupakan jenis deskriptif kualitiatif. Pendekatan yang diguakan dalam penelitian ini adalah pendekatan kualitatif. Sedangkan jenis penelitiannya menerapjkan jenis deskriptif. Sebagaimana diungkapkan Creswell (2015) bahwa penelitian deskriptif kualitatif ini merupakan pendekatan ilmiah dan mengandalkan manusia sebagai instrumen penelitian. Pada penelitian ini sajian data hasilnya dipaparkan dalam bentuk deskriptif kualitatif. Data yang terkumpul berbentuk narasi, kata-kata, gambar, cerita dan bahkan data berupa angka di rangkai menjadi sebuah kesimpulan yang berbentuk deskripsi.

Sumber data utama dalam penelitian ini berupa sumber data tertulis dan hasil wawancara. Sumber data tertulis yang digunakan meliputi buku-buku tentang permainan tradisional, jurnal ilmiah, situs pemerintah daerah Yogyakarta, arsip kebudayaan, penelitian-penelitian yang berkaitan dengan permainan tradisional, surat kabar, serta dokumen pribadi dan dokumen resmi lain yang berhubungan dengan permainan tradisional (dolanan anak) di Daerah Istimewa Yogyakarta. Adapun data wawancara diperoleh dari ahli serta pemerhati kebudayaan Daerah Istimewa Yogyakarta. Data wawancara dilakukan untuk mendukung serta menguatkan data yang diperoleh dari hasil penelusuran data tertulis. Untuk memperoleh data yang valid dilakukan perbandingan antar data yang ditemukan, baik secara sumber maupun secara waktu.

Analisis data pada penelitian ini menggunakan jenis analisis kualitatif. Setiap catatan harian yang dihasilkan dalam pengumpulan data yang berasal dari analisis dokumen, observasi serta hasil wawancara diseleksi dan dirangkum menjadi sebuah narasi deskripsi. Penyempurnaan data dari data yang telah terkumpul dilakukan setiap saat jika ditemukan kekurangan dari data yang sudah ada. Muara dari seluruh kegiatan analisis data kualitatif terletak pada pelukisan atau penuturan tentang apa yang berhasil diteliti.

\section{HASIL DAN PEMBAHASAN}

Kapastian jumlah dan jenis permainan tradisional yang ada di D.I Yogyakarta masih membutuhkan 
penggalian yang lebih mendalam. Sebagaimana yang diungkapkan oleh Purwaningsih (2006) bahwa macam, jumlah serta maksud semula dari permainan tradisional hanya dapat ditelusuri dari sisa-sisa beberapa permainan tradisional yang ada pada ahir abad ke 19 dan awal abad 20. Keberadaan permainan tradisional saat ini merupakan hasil pemetaan dari permainan tradisional yang masih eksis hingga periode ahir abad 19 tersebut. Menurut Dinas Kebudayaan Propinsi Daerah Istimewa Yogyakarta yang dilansir dalam situs resmi dinas kebudayaan propinsi DIY terdapat 27 permainan tradisional yang berbasis di D.I. Yogyakarta, diantaranya: [Times New Roman, 12].

Data pada Tabel 1 peneliti komparasikan dengan beberapa sumber hasil penelitian lain dalam bentuk buku, laporan penelitian maupun jurnal ilmiah. Hasil pembandingan data menyebutkan bahwa selain ke duapuluh tujuh permainan tradisional diatas, terdapat 10 permainan tradisional lain yang juga pernah dan atau saat ini masih eksis di yogyakarta. Kesebelas permainan tradisional lain yang juga pernah dan masih eksis di yogyakarta terdapat pada Tabel 2.

Sehingga dapat disimpulkan bahwa terdapat minimal 38 permainan tradisional yang pernah ada dan atau masih eksis di Daerah Istimewa Yogyakarta.
Ketidakpastian jumlah ini menunjukkan dinamisnya persebaran jenis permainan tradisional di lintas daerah di indonesia bahkan di dunia. Dari hasil penelitian juga menyebutkan, tidak sedikit permainan tradisional yang memiliki ragam nama yang berfariasi yang terdapat di daerah lain, namun cara dan metode permainannya relatif sama.

Tabel 1. Permainan tradisional yang berbasis di D. I Yogyakarta menurut Dinas kebudayaan DIY.

\begin{tabular}{|c|c|c|c|}
\hline No & Nama Permainan & No & $\begin{array}{c}\text { Nama } \\
\text { Permainan }\end{array}$ \\
\hline 1 & Dolanan Soyang & 15 & $\begin{array}{l}\text { Dholanan } \\
\text { Gejogan }\end{array}$ \\
\hline 2 & $\begin{array}{l}\text { Dholanan Dayoh- } \\
\text { dayohan }\end{array}$ & 16 & $\begin{array}{l}\text { Dholanan } \\
\text { Genukan }\end{array}$ \\
\hline 3 & $\begin{array}{l}\text { Dholanan } \\
\text { Dhingklik oglak } \\
\text { aglik }\end{array}$ & 17 & $\begin{array}{l}\text { Dholanan } \\
\text { Bas basan }\end{array}$ \\
\hline 4 & Dholanan Sobyang & 18 & $\begin{array}{l}\text { Dholanan } \\
\text { Jamuran }\end{array}$ \\
\hline 5 & $\begin{array}{l}\text { Dholanan Lintang } \\
\text { alihan }\end{array}$ & 19 & Adu kemiri \\
\hline 6 & $\begin{array}{l}\text { Dholanan Ancang- } \\
\text { ancang alis }\end{array}$ & 20 & Bekel \\
\hline 7 & $\begin{array}{l}\text { Dholanan Cublak- } \\
\text { cublak suweng }\end{array}$ & 21 & Egrang \\
\hline 8 & Dholanan Benthik & 22 & Gasing \\
\hline 9 & Dholanan Gatheng & 23 & $\begin{array}{l}\text { Layang- } \\
\text { layang }\end{array}$ \\
\hline 10 & $\begin{array}{l}\text { Dholanan } \\
\text { Dhakon/congklak }\end{array}$ & 24 & $\begin{array}{l}\text { Nini } \\
\text { Thowong }\end{array}$ \\
\hline 11 & $\begin{array}{l}\text { Dholanan Jeg- } \\
\text { jegan/betengan }\end{array}$ & 25 & Paseran \\
\hline 12 & Dholanan Lepetan & 26 & $\begin{array}{l}\text { Thuprok } \\
\text { Thuprok }\end{array}$ \\
\hline 13 & $\begin{array}{l}\text { Dholanan } \\
\text { Gamparan }\end{array}$ & 27 & $\begin{array}{l}\text { Watu } \\
\text { Gatheng }\end{array}$ \\
\hline 14 & $\begin{array}{l}\text { Dholanan Gobag } \\
\text { Sodor }\end{array}$ & & \\
\hline
\end{tabular}

Terdapat beberapa klasifikasi yang digunakan dalam memilah permainan tradisional. Klasifikasi tersebut sekaligus sebagai bentuk pemetaan potensi dari permainan tradisional. Klasifikasi pertama yang digunakan peneliti untuk memilah antar permainan tradisional 
adalah klasifikasi yang dibuat oleh

Dharmamulya (2004) yang membedakan karakteristik permainan tradisional menjadi 3 kelompok yaitu: permainan tradisional kelompok bernyanyi dan bermain, kelompok bermain dan berpikir, serta kelompok bermain dan berkompetisi.

Tabel 2. Permainan tradisional yang eksis di D.I Yogyakarta berdasarkan beragam

\begin{tabular}{llll}
\multicolumn{4}{c}{ sumber } \\
\hline No & $\begin{array}{c}\text { Nama } \\
\text { Permainan }\end{array}$ & No & Nama Permainan \\
\hline 28 & Engklek & 33 & $\begin{array}{l}\text { Kodok- } \\
\text { kodokan/gotri }\end{array}$ \\
\hline 29 & Cician & 34 & Lompat tali \\
\hline 30 & Dam-daman & 35 & Petak umpet \\
\hline 31 & $\begin{array}{l}\text { Gembatan/ } \\
\text { boy-boyan }\end{array}$ & 36 & Sepak tekong \\
\hline 32 & Kelereng & 37 & $\begin{array}{l}\text { Wak-wak } \\
\text { gong/sepur-epuran }\end{array}$ \\
\hline
\end{tabular}

Kelompok pertama adalah kategori kategori bernyanyi dan bermain. Pada kategori kelompok bernyanyi dan bermain indikator yang digunakan untuk menyeleksi permaianan tradisional adalah adanya aktifitas bernyanyi yang dilakukan anak-anak sembari bermain. Dalam kelompok ini para pemain menyanyikan lagu dan berdialog di tengah-tengah permainan. Permainan ini kebanyakan dilakukan oleh anakanak perempuan. Permainan ini mengandung nilai rekreasi sosial. Adapun yang termasuk dalam kelompok permainan ini adalah: Dolanan soyang, Dolanan Dayohdayohan, Dingklik Oglak aglik, Dolanan Sobyang, Dolanan Ancang-ancang Alis, Dolanan
Cublak-cublak suweng, dan Lepetan.

Kelompok kedua adalah kategori kategori bermain dan berpikir. Indikator karakter yang digunakan untuk menyeleksi permainan tradisional menjadi kelompok ini adalah adanya unsur adu strategi, taktik atau teknik khusus untuk memainkan permainan kelompok ini. Mesipun strategi identik dengan kompetisi namun dalam kategori ini tidak semua berujung pada sasaran menang-kalah. Diantara permainan tradisional dalam kategori ini yang tidak berujung menang kalah diantaranya adalah layang-layang.

Dalam permainan kategori bermain dan berpikir ini anak harus lebih berkonsentrasi dan berpikir untuk mengatur strategi untuk memecahkan masalah. Permainan tradisional yang masuk pada kategori ini tidak hany mengandung unsur bermain, namun anak-anak diajak untuk berpikir ditengah aktifitas bermain. Beberapa permainan tradisional yang termasuk dalam kelompok ini adalah: Lintang alihan, Cublak-cublak suweng, Dhakon, Betengan, Gamparan, Gobak Sodor, Bekel, Layang-layang, Watu Ghatheng, Dham-dhaman, Dhelikan, dan Lompat Tali.

Kelompok ketiga adalah kategori kategori bermain dan berkompetisi. Indikator karakter yang digunakan untuk menyeleksi permainan tradisional menjadi kelompok ini adalah adanya unsur kompetisi untuk meraih juara. Hal ini karena akhir dari permainan kelompok ini adalah menang dan kalah. Kompetisi yang dilakukan dapat berupa antar kelompok, satu-lawan satu, atau satu lawan banyak/kelompok.

Permainan kelompok ini merupakan permainan yang mendasarkan pada 
kekuatan fisik berupa pertandingan antara satu orang dengan kelompok atau kelompok dengan kelompok. Salah satu hal yang diajarkan pada permainan tradisional kategori ini adalahkarakter sportifitas. Karena dalam berkompetisi anak tetap diminta untuk sportif terhadap hasil yang didapat. Biasanya pemenang akan mendapatkan hadiah sedangkan yang kalah akan mendapatkan hukuman. Adapun yang termasuk dalam kategori ini adalah: Dolanan Sobyang, Ancangancang alis, Benthik, Dhakon, Betengan, Gamparan, Gobak Sodor, Bekel, Egrang, cublakcublak suweng, Gasing, Layanglayang, Dolanan Thuprok-thuprok, Watu gatheng, Dhelikan, dan Lompat tali.

Pada pembagian karakter diatas hampir tidak ada permainan tradisional yang berkarakter tunggal. Mayoritas permainan tradisional memiliki fleksibilitas karakter. Beberapa permainan tradisional merupakan kombinasi antara bermain-bernyanyi dan bermain berkompetisi, beberapa permainan tradisional lain memiliki karakter bermain-berpikir dan bermain berkompetisi. Sehingga dapat ditarik kesimpulan awal bahwa dalam satu permainan tradisional memiliki keragaman karakter yang terkandung didalamnya.

Klasifikasi kedua yang digunakan peneliti untuk memilah antar permainan tradisional adalah klasifikasi tentang permainan tradisional berdasarkan kelompok pengguna. Berdasarkan klasifikasi ini diharapkan penggunaan permainan tradisional dalam konteks pembelajaran di sekolah dasar lebih mudah untuk di sesuaikan dengan jumlah keterlibatan siswa. Adapun klasifikasinya adalah sebagai berikut:

a. Permainan yang pelakunya satu sampai dengan dua orang, diantaranya adalah: Dhakon, Bekel, Gasing, Layang-layang, Paseran, Dolanan Thuprok-tuprok, Dhamdhaman, dan Dolanan kelereng. Kedelapan permainan Tradisional tersebut memungkinkan untuk dilakukan sendiri, namun demikian tidak menutup kemungkinan kedelapan permainan tradisional tersebut dilakukan secara bersamaan. Jadi pada prinsipnya kedelapan permainan tradisional pada klasifikasi ini memungkinkan untuk dilakukan secara individu namun tidak sepenuhnya harus dilakukan secara sendirian, bahkan akan lebih meriah jika dilakukan secara bersama-sama.

b. Permainan yang bisa digunakan oleh kelompok kecil (3 sd 5 orang), diantaranya adalah: Dolanan dayoh-dayohan, Dingklik oglak aglik, Cublak-cublak suweng, Benthik, Lepetan, Gamparan, Bekel, Egrang, Gasing, Layanglayang, Nini Thowong, Paseran, Dolanan Thuprok-tuprok, Watu Ghatheng, Dhelikan, Lompat tali dan Dolanan Kelereng. Permainan tradisional pada kategori ini dapat dilakukan didalam ruangan maupun di luar ruangan. Jumlah yang sedikit memberikan fleksibilitas pada para pemain untuk menentukan lokasi permainan 
antara di dalam ruangan maupun di luar ruangan.

c. Permainan yang digunakan oleh kelompok sedang (6 sd 10 orang), diantaranya adalah: Dolanan soyang, Dolanan dayoh-dayohan, Dolanan Sobyang, Lintang alihan, Dolanan ancangancang alis, Cublak-cublak suweng, Benthik, Betengan, Lepetan, Gamparan, Gobak sodor, Egrang, Gasing, Layang-layang, Paseran, Dolanan Thuprok-thuprok, dan Dolanan kelereng.

d. Permainan yang didunakan oleh kelompok besar (lebih dari 10 orang), diantaranya adalah: Dolanan Soyang, Lintang Alihan, Dolanan Ancang-ancang Alis, Betengan, Egrang, Layanglayang, Paseran, dan Dolanan Thuprok-thuprok.

Dari semua permainan tradisional yang ada tidak ada satupun permainan tradisional yang dilakukan secara individualistik. Bahkan mayoritas permainan tradisional dilakukan dalam bentuk teamwork atau bersamaan dengan orang lain. Data analisi diatas menunjukkan bahwa mayoritas permainan tradisional perlakuannya didominasi dalam bentuk kelompok keci (3 sd 5 orang) dan kelompok sedang (6 sampai 10 orang). Hal tersebut mengindikasikan bahwa permainan tradisional mengarahkan pada aspek sosial atau kompetensi sosial. Hal ini sangat berkebalikan dengan karakter pada permainan modern (games berbasis apikasi komputer), yang banyak mengandalkan aspek individualsme dan kompetisi.

Tabel 3. Pengelompokan permainan tradisional

Yogyakarta berdasarkan kelompok pengguna

\begin{tabular}{|c|c|c|}
\hline No & $\begin{array}{l}\text { Klasifikasi } \\
\text { menurut } \\
\text { kelompok } \\
\text { pemain }\end{array}$ & Jenis Permainan Tradisional \\
\hline 1. & $1-2$ org & $\begin{array}{l}\text { Dhakon, Bekel, Gasing, } \\
\text { Layang-layang, Paseran, } \\
\text { Dolanan Thuprok-tuprok, } \\
\text { Dham-dhaman, dan Dolanan } \\
\text { kelereng. }\end{array}$ \\
\hline 2. & $3-5$ org & $\begin{array}{l}\text { Dolanan dayoh-dayohan, } \\
\text { Dingklik oglak aglik, Cublak- } \\
\text { cublak suweng, Benthik, } \\
\text { Lepetan, Gamparan, Bekel, } \\
\text { Egrang, Gasing, Layang- } \\
\text { layang, Nini Thowong, } \\
\text { Paseran, Dolanan Thuprok- } \\
\text { tuprok, Watu Ghatheng, } \\
\text { Dhelikan, Lompat tali dan } \\
\text { Dolanan Kelereng }\end{array}$ \\
\hline 3. & $6-10$ org & $\begin{array}{l}\text { Dolanan soyang, Dolanan } \\
\text { dayoh-dayohan, Dolanan } \\
\text { Sobyang, Lintang alihan, } \\
\text { Dolanan ancang-ancang alis, } \\
\text { Cublak-cublak suweng, } \\
\text { Benthik, Betengan, Lepetan, } \\
\text { Gamparan, Gobak sodor, } \\
\text { Egrang, Gasing, Layang- } \\
\text { layang, Paseran, Dolanan } \\
\text { Thuprok-thuprok, dan Dolanan } \\
\text { kelereng. }\end{array}$ \\
\hline 4. & $>10$ org & $\begin{array}{l}\text { Dolanan Soyang, Lintang } \\
\text { Alihan, Dolanan Ancang- } \\
\text { ancang Alis, Betengan, Egrang, } \\
\text { Layang-layang, Paseran, dan } \\
\text { Dolanan Thuprok-thuprok. }\end{array}$ \\
\hline
\end{tabular}

Pengelompokan permainan tradisionl berdasarkan jumlah pemain ini dapat dijadikan pijakan bagi guru disekolah saat memilih permainan tradisional mana yang hendak digunakan. Jumlah keterlibatan siswa dalam permainan tradisional berkorelasi langsung dengan jumlah peserta didik yang dimiliki sekolah di setiap rombongan belajar. Kondisi lain yang berhubungan dengan jumlah pemain dalam permainan 
tradisional ini adalah, keberadaan sarana dan prasarana. Jumlah pemain secara tidak langsung berhubungan dengan keluasan lokasi pembelajaran saat menggunakan permainan tradisional ini. Permainan tradisional dengan jumlah pemain kecil (1-2 orang) dan beberapa permainan kelompok pemain sedang (3- 5 orang \& 6-10 orang) masih dapat dilakukan di dalam ruang kelas. Namun semua permainan tradisional dengan jumlah pemain besar (diatas 10 orang) serta mayoritas permainan tradisional dengan jumlah pemain sedang membutuhkan lahan yang cukup luas untuk memainkannya. Hal tersebut berhubungan dengan ketersediaan sarana prasarana sekolah.

Klasifikasi Ketiga yang digunakan peneliti untuk memilah antar permainan tradisional adalah klasifikasi tentang permainan tradisional dilakukan oleh Bishop\&Curtis (2005) yang menyebutkan bahwa permainan tradisional terklasifikasi menjadi tiga kategori, yaitu 1) Permainan yang sarat dengan muatan verbal, 2) Permainan yang sarat dengan muatan imaginatif, 3) Permainan yang sarat dengan muatan fisik:

Kelompok pertama, yaitu permainan yang sarat dengan muatan verbal. Indikator yang digunakan dalam pengelompokkan permainan tradisional dalam kategori kelompok pertama ini adalah: a) adanya unsur adialog dalam permainan. Dialog ini dapat terjadi dalam aturan permainan sebagai langkah permainan maupun dialog dalam sebuah permainan peran. Permainan tradisional dalam kategori ini adalah: dolanan soyang, dayoh-dayohan, lepetan, dan sepur-sepuran; b) adanya proses bernyanyi yang sekaligus sebagai bentuk dialog (dingklik oglak aglik, sobyang, ancang ancang alis, cublakcublak suweng, jamuran, gotri/kodokkodokan).

Kelompok kedua, yaitu permainan yang sarat dengan muatan imajinasi. Indikator yang digunakan dalam pengelompokkan permainan tradisional dalam kategori kelompok imajinatif ini adalah: a) adanya unsur bermain peran. Beberapa permainan tradisional yang mengandung indikator bermain peran ini adalah: dholanan soyang, dayoh-dayohan, lepetan, jamuran, dehlikan, sepak tekong, sepur-sepuran; b) adanya unsur imajinasi matematis. Beberapa permainan tradisional yang mengandung indikator bermain peran ini adalah: cublak-cublak suweng, dakon, dam-daman, engklek, kelereng; c) adanya unsur harmoni sebuah irama. Dholanan gejogan merupakan satu-satunya yang terkndung indikator harmonisasi irama; d) adanya unsur strategi kekompakan team. Beberapa permainan tradisional yang mengandung indikator bermain peran ini adalah: genukan dan cublak suweng; e) adanya unsur khayalan supranatural. Dholanan nini thowong merupakan satusatunya permainan tradisional yang terkandung unsur khayalan supranatural ini.

Kelompok ketiga, yaitu permainan yang sarat dengan muatan fisik. Pada kelompok ketiga ini semua permainan tradisional diidentifikasi memiliki olah gerak atau fisik. Olah gerak dan fisik dalam kategori ketiga ini terbagi menjadi 
dua yaitu permainan tradisional dengan gerak fisik yang berat dan gerak fisik ringan. Permainan dalam kategori fisik yang mengandung unsur olah atau gerak fisik berat, diantaranya: lonpatloncat, lari-lari, serta kombinasi. Ragam permainan radisional yang termasuk didalamnya adalah dhingklik oglak aglik, lintang alihan, betengan, gobag sodor, layang-layang, engklek, kodogkodokan, lompat tali, gebokan, dhelikan, sepak tekong. Indikator kategori kedua adalah permainan tradisional dengan gerak fisik yang ringan. Beberapa aktifitas olahraga ringan diantaranya: a) ayunan tangan dengan fokus pada titik benda (gasing, adu kemiri,gamparan, benthik, gejogan, watu gatheng); b) kecekatan dan kecermatan dan kecepatan gerak (dolanan bekel, gasing, ); c) keseimbangan tubuh (egrang, tuprok-tuprok); d) tenaga dan fokus (paseran, kelereng).

Berdasarkan beberapa indikator yang terdapat pada masing-masing klasifikasi diatas, maka pengelompokan secara umum permainan tradisional berdasarkan klasifikasi Bishop\&Curtis (2005) adalah sebagaimana dalam Tabel 4 .

Berdasarkan tabel 4 diatas, nampak bahwa permainan tradisional dengan kategori verbal terdapat 10 permainan tradisional. Permainan tradisional dengan kelompok imaginatif terdapat 16 permainan. Sedangkan permainan tradisional pada kelompok fisik terdapat 21 jenis permainan. Dengan kata lain permainan tradisional yang ada di yogyakarta tersebar di seluruh klasifikasi. Hal ini terlihat dari hampir semua kategori (dari 3 kategori yang ada) terisi dengan jumlah permainan tradisional yang cukup banyak.

Tabel 4. Pengelompokan permainan tradisional Yogyakarta berdasarkan klasifikasi Bishop\&Curtis

\begin{tabular}{cll}
\hline No & Klasifikasi & Jenis permainan \\
\hline 1. & Verbal & Dholanan soyang; Dayoh- \\
& dayohan; Dhingklik oglak aglik; \\
& Dholanan Sobyang; Ancang- \\
& ancang alis; cublak-cublak \\
& suweng; lepetan; jamuran; \\
& sepur-sepuran, gotri/kodok- \\
& kodokan. \\
\hline Imaginatif & Dholanan soyang; dayoh- \\
& dayohan; ciblak cublak suweng; \\
& dhakon; lepetan; gejogan; \\
& genukan; Bas basan; jamuran; \\
& nini thowong; engklek; dam- \\
& daman; kelereng; dhelikan; \\
& sepak tekong; sepur-sepuran. \\
& Dhingklik oglak aglik; Lintang \\
& Alihan; benthik; bhetengan; \\
& gamparan; gobag sodor; adu \\
& kemiri; dholanan bekel; \\
& Dholanan egrang; dholanan \\
& gasing; layang-layang; dholanan \\
& paseran; dholanan tuprok- \\
& tuprok; watu gateng; engklek; \\
& gebokan; kelereng; gotri/kodok- \\
& kodokan; lompat tali; dhelikan; \\
& sepak tekong. \\
\hline 3. Fisik &
\end{tabular}

\section{SIMPULAN}

Merujuk pada pemaparan hasil penelitian dan pembahasan pada bab sebelumnya, maka kesimpulan pada penelitiannya adalah:

Terdapat minimal 37 permainan tradisional yang ada di daerah Istimewa Yogyakarta. ini menunjukkan dinamisnya persebaran jenis permainan tradisional di lintas daerah di indonesia bahkan di dunia. Dari hasil penelitian juga menyebutkan, tidak sedikit permainan tradisional yang memiliki ragam nama 
yang berfariasi yang terdapat di daerah lain, namun cara dan metode permainannya relatif sama.

Terdapat tiga klasifikasi untuk memilah 37 permainan tradisional berbasis di D. I Yogyakarta ini. Klasifikasi pertama yaitu permainan tradisional dalam kelompok bernyanyi dan bermain (ada 7 permainan tradisional); kelompok bermain dan berpikir (ada 12 permainan tradisional); dan kelompok bermain dan berkompetisi (ada 15 permainan tradisional). Klasifikasi kedua yang digunakan adalah berdasarkan kelompok pengguna. Terdapat empat kategori permainan tradisional berdasarkan kelompok pengguna, yaitu Permainan yang pelakunya hanya satu sampai dengan dua orang (ada 8 jenis permainan); permainan yang digunakan oleh kelompok kecil, 3 sampai 5 orang (ada 17 jenis permainan); permainan yang digunakan oleh kelompok sedang, 6 sampai 10 orang (ada 17 permainan); serta permainan yang digunakan oleh kelompok besar, diatas 10 orang (ada 8 jenis permainan). Klasifikasi ketiga klasifikasi permainan tradisional berdasarkan muatannya. Pada klasifikasi ketiga ini terdapat tiga kategori, yaitu permainan yang sarat dengan muatan verbal (ada 10 jenis permainan); permainan yang sarat dengan muatan imajinasi (ada 16 jenis permainan). Serta permainan yang sarat dengan muatan fisik (ada 21 jenis permainan)
Dapat disimpulkan bahwa ragam karakter permainan tradisional sangat luas, mulai yang individual, kelompok kecil hingga kelompok sangat besar; mulai dari yang bermuatan verbal, imajinasi hingga yang bermuatan fisik; serta mengandung kompetensi bernyanyi, bermain, berpikir hingga berkompetisi. Berdasarkan Kesemua kategori tersebut ada jenis permainan tradisional yang masuk mewakili masing-masing kategori tersebut.

\section{DAFTAR RUJUKAN}

Anshory CH, HM Nasrudin. (2013). Strategi kebudayaan. Malang: UB Press.

Bishop, J.C. \& Curtis, M. (2005). Permainan anak-anak zaman sekarang. Editor: Yovita Hadiwati. Jakarta: PT. Grasindo.

Catron, C.E. \& Allen, J. (1999). Early Childhood Curriculum A CreativePlay Model. New Jersey: Merill, Prentice-Hall.

Creswell, John. (2015). Riset pendidikan perencanaan, pelaksanaan, dan evaluasi riset kualitatif dan kuantitatif edisi kelima. Alih bahasa oleh Helly Prajitno Soetjipto\&Sri Mulyantini Soetjipto. Yogyakarta: Pustaka Pelajar.

Darmawan, Oksimana. (2016). Penanaman budaya anti kekerasan sejak dini pada pendidikan anak melalui kearifan lokal permainan tradisional. Jurnal Penelitian HAM. Volime 7 no. 2 Desember 2017. Hal $111-124$.

Dharmamulya, Sukirman, dkk. (2004). Permainan Tradisional Jawa. Yogyakarta: Kepel Press. 
Garvey, Catherine. (1990). Play:

The Developing Child (enlarged edition). Cambridge: Harvard University Press.

Huizinga, Johan. (1990). Homo Ludens: a Study of the Play Element in Culture,Boston: The Beacon Press.

Husni, Emir Mauludin \& Fatullah, Agus. 2016. Kategorisasi pengguna internetdi kalangan pelajar SD dan SMP menggunakan metode twostep cluster. Prosiding seminar nasional aplikasi teknologi informasi 2016. Yogyakarta.

King, Anna. L. S. at al. (2014). Nomophobia: Impact of Cell Phone Use Interfering with Symptoms and Emotions of Individuals with Panic Disorder Compared with a Control Group. Clinical Practice \& Epidemiology in Mental Health. Vol. 10, 2014: $28-35$

Mustafa, Siti Ezaleila, dan Hamzah, Azizah. (2010). Media sosial: tinjauan terhadap laman jaringan sosial dalam talian tempatan. Jurnal Pengajian Media Malaysia. Vol. 12, No. 2, 2010: 37-52.

Mustafa, Siti Ezaleila. (2013) Media sosial di malaysia dan Indonesia: penggunaannya sebagai alat komunikasi, kolaborasi, dan jaringan digital. Jurnal Pengajian Media Malaysia. Vol. 15 No. 2, 2013: 71-85.

Munawaroh, Siti. (2011). Permainan Anak Tradisional sebuah Model Pendidikan Dalam Budaya. Jatra Jurnal sejarah dan Budaya. Vol. VI. No 12, 2011: 208 $-216$.

Nadlir. (2014). Urgensi Pembelajaran Berbasis Kearifan Lokal. Jurnal Pendidikan Agama Islam. Volume 2 No. 2: Hal. 299-330.

Prasetyo, Yogi. (2015). Kebijakan pendidikan berkemajuan melalui inovasi pembelajaran yang berkeadaban. Prosiding seminar nasional Inovasi pembelajaran untuk pendidikan berkemajuan. FKIP Universitas Muhammadiyah Ponorogo, 7 November 2015. Hal. 216-223.

Purwaningsih, Ernawati. (2006). Permainan tradisional anak: salah satu khasanah budaya yang perlu dilestarikan. Jatra. Volime 1 no. 1: hal $40-46$.

Ruyadi, Yadi. (2010). Model pendidikan karakter berbasis kearifan lokal. Proceedings of The 4th International Conference on Teacher Education; Join Conference UPI \& UPSI Bandung, Indonesia, 8-10 November 2010; Hal 576 - 594.

Sudono, Anggani. (2006). Sumber Belajar dan Alat Permainan: untuk pendidikan anak usia dini. Jakarta: PT Grasindo.

Suhartini. (2009). Kajian Kearifan Lokal Masyarakat dalam Pengelolaan Sumberdaya Alam dan Lingkungan. Prosiding Seminar Nasional Pendidikan dan Penerapan MIPA, Fakultas MIPA, Universitas Negeri Yogyakarta. hal. $206-219$.

www.voaindonesia.com, Selasa, 08 Desember 2015 
www.dunia.news.viva.co.id/news

Yudiwinata, Hikmah Prisia\&Handoyo, Pambudi. (2014). Permainan tradisional dalam budaya dan perkembangan anak. Paradigma. Volume 2 No. 3 tahun 2014.

Wulandari, Wahyu trias\& Mundilarto. (2016).

Pengembangan perangkat pembelajaran fisika aktif tipe learning tournament berbaisis local wisdom. Cakrawala pendidikan. Th XXXV, No. 3. Hal, 365-377. 